\title{
DEVELOPING BUT DISCRIMINATIVE THEORIES ON POLITICAL PARTIES
}

\author{
Ulla Fionna \\ Department of Politics and International Relations, Faculty of Arts, Macquarie \\ University and Department of Government and International Relations, Faculty of \\ Arts, The University of Sydney, Australia \\ Email: ulla@ullafionna.com / URL: www.ullafionna.com
}

\begin{abstract}
This article reviews and summarises the trends in the development of theories on political parties. In particular, the inherent and overwhelming trend of Western-focused will be addressed. Through the discussion on the contemporary trends in theories of political parties, the article describes the one-sidedness of the theories and the oversight against parties from other regions. However, because of the establishment of these theories, the trend will continue as the theories will be used as benchmark for the development of parties in other parts of the world.
\end{abstract}

Keywords: Political parties, democracy, party typologies, party decline

\section{TEORI-TEORI TENTANG PARTAI POLITIK BERKEMBANG TAPI DISKRIMINATIF}

ABSTRAK. Artikel ini membahas dan meringkas kecenderungan-kecenderungan dalam perkembangan teori-teori tentang partai politik. Secara khusus, kecenderungan kuat untuk memfokuskan diri pada partai-partai dari dunia Barat menjadi inti artikel ini. Melalui pembahasan tentang kecenderungankecenderungan kontemporer dalam teori-teori ini, artikel ini menggambarkan ketimpangan dan kelalaian terhadap partai-partai dari belahan dunia lainnya. Akan tetapi, karena kemapanan teori-teori ini, tren ini akan terus berlanjut, karena dipakai sebagai tolok ukur untuk perkembangan partai di area-area lainnya.

Katakunci: Partai politik, demokrasi, tipologi partai, party decline

\section{DEVELOPING BUT DISCRIMINATIVE THEORIES ON POLITICAL PARTIES}

The fact that parties first developed in Western countries have resulted in Western oriented theories as well. Because trends of floating voters and the decline of mass membership have also been shown in the Western countries, discussion on parties have paid even less attention to other parts of the world. As such, in examining parties scholar inevitably have to refer to western parties' experiences although other region's parties may have different circumstances. Nonetheless, the western focus has remained an important contribution to the study of parties. 
The main argument here is that theories on political parties are largely based and focused on Western countries. This trend is understandable as the early and arguably most quoted works on theories on political parties, such as the ones by Duverger (1954), Neumann (1956) and Michels (1959), were based on European countries. Although attention has been given to parties from other parts of the world; the study of political parties is still very much Western-dominated (as explained in the subsequent sections).

The first section of this essay focuses on the main and contemporary themes of theories on political parties - it is explained there that contemporary discussions on political parties are heavily based on European countries. The second section elaborates on the literature on political parties, to demonstrate that the existing literature is heavily Western-based and only very limited portion focuses on parties from other parts of the world. The third section focuses on party organization, and the fourth section talks about various typologies of parties. Finally, the fifth section concludes the argument.

Literature for this essay is derived from books and journals. Aside from books focusing on political parties, I also consult books on democratisation theories given the positive correlation between democratic transition and the functioning of parties. I rely heavily on the works of Gunther, Montero, Linz and Richard Hofferbert - prominent political scientists whose latest works on political scientists seem to accumulate the latest trends of the study. I also refer to the 'older' works on political parties to look at the early and 'traditional' theories. The journal that I refer to is Party Politics.

\section{CONTEMPORARY ISSUES ON POLITICAL PARTIES}

As Gunther, Montero and Linz argue, political parties are crucial for democracy as they are the 'principal mediators between the voters and their interest' (Gunther, Montero, and Linz, 2002: 58). The parties are also the vehicles for voters to gather with others who have similar interest, and thus strengthen (although sometimes only in numbers) their position to demand their will. This is why the study of political parties is 'an essential contribution to the study of democracy', and theories on political parties can enrich theories on democracy (Gunther, Montero, and Linz, 2002: 58). As democracy became increasingly popular with the fall of non-democratic regimes around the globe - particularly after the fall of Communism in the Easter Europe in the 1980s, the study of political parties became more popular as well.

Democratisation supports and enhances the demand for political participation. The rise of new political parties, as a result of democratisation is an interesting additional aspect to the study of democracy. Klingemann and Fuchs state that one of the possible consequences of this demand is the diminishing significance of voting as the most institutionalised form of participation; which is strengthened when citizens do not feel that the contending parties are not sensitive to new demands (Klingemann and Fuchs, 1995: 18). However, the same feeling is 
advantageous for emerging parties, as they can claim to be more accommodative to the new demands and needs. Pridham notes that these parties, can be the determining factor for consolidated democracy (Pridham,1995: xii).

At the same time, another trend has emerged among the more established democracies, notably in Western states. This trend, dubbed the 'decline of parties' is characterised mainly by the diminishing linkage between parties and the voters. Scholars have argued that there is waning partisanship and membership in parties, mainly in Europe (Schmitt and Holmberg in Klingemann and Fuchs, 1995: 95). There is possibly a downturn in the strength of party identification as a result of, among others, mass education, the expansion of mass media, and the emergence of other forms of societal participation - or, to sum up in one word: modernisation (Schmitt and Holmberg, in Klingemann and Fuchs, 1995: 96). Thus, there has emerged a new generation or class of 'new citizens' who need less political organization and therefore have less ties with political parties (Schmitt and Holmberg, in Klingemann and Fuchs, 1995: 96). This trend is seen as a nightmare for the more traditional political scientists who glorify partisanship and party membership as a strong sign of democracy.

The argument that parties are facing a crisis has been supported by other scholars. Hans Daalder distinguishes the crisis of party as: the denial of party (the body of thought that denies the need for party and believe that parties are threat to good society), the selective rejection of party (among those who think certain types of parties as 'good' and others 'bad'), the selective rejection of party systems (the argument that particular party systems are 'good' and others 'bad'), and the redundancy of party (the notion that parties are matters of the past) (Daalder in Gunther et al (eds.), 2002: 39). Daalder argues that the different kinds of sentiment against parties have developed since the time of the formation of parties in Europe, and that critics of parties should exercise care when launching their criticisms (Daalder in Gunther et al., 2002: 39-41, 54-56). Jean Blondel points to the 1990 s as the time during which 'serious questions were raised about political parties, in many, if not all, Western European countries" - although he believes that the trend started in 1970s (Blondel in Gunther et al., 2002: 233).

Despite the decreasing support for political parties, there is significant amount of conviction that parties truly are important; as other scholars believe that they will remain inevitable. As Bryce note, 'no free country has been without them, and no one has shown how representative government could work without them' (Gunther et al., 2002: 3). Schattschneider argues that 'modern democracy is unthinkably save in terms of political parties', and Stokes claims that "parties are endemic and unavoidable to democracy" (Gunther et al., 2002: 3). Gunther et al also sighted the outburst of comparative study on parties and the birth of the journal Party Politics as a sign that the importance of parties is in fact getting stronger, and that studies of parties should remain important in political science (Gunther et al., 2002: 3). 
Contemporary studies of political parties have noted other 'modern' trends. One of the strongest trend supports the notion that parties are somewhat decreasing in power - because increasingly people are becoming floating voters. Linz argues that the new democracies will have 'fewer voters with a strong party identification, people are actually freer to choose but only the degree of loyalty is questionable' (Linz in Hadenius, 1997). Thus, it is arguably harder for parties to attract members, because there is decreasing closeness in relationship between being a party member and voting - voters feel they do not have to be a member to vote for a party. Furthermore, by not being a particular party member, voters feel more freedom in voting for another party in the next election, if they choose to do so.

The rapid growth of media has also formed a different kind of interaction between party and its voters. Arguably promotion and campaigners have been able to reach more audience thanks to radio, television, and the internet. Katz and Mair investigate the changes in party press caused by the evolution of media - they note that television has required parties to choose their best personalities to be given broadcasting time, and these 'newsworthy' party personnel can communicate directly with the pubic without the intervention or need for party organization (Katz and Mair in Gunther et al., 2003: 131). Thus, these new pattern of communication requires new varieties and levels of professional skills in political parties (Katz and Mair in Gunther et al., 2003: 131).

\section{LITERATURE ON POLITICAL PARTIES}

As mentioned at the beginning of the first section, one important theme for literature on political parties is the fact that parties and party institutionalisation are central in the study of democratisation, and thus there is a significant part that parties occupy in the literature on democratisation. Huntington points to election as the backbone of democracy (Huntington, 1991: 109, 174), which means that there must be full-functioning parties in a democracy. The same argument was made by Linz and Stepan, who believe in the need for free and inclusive electoral contestation in a consolidated democracy (Stepan and Linz, 1996: 14). Mainwaring and Scully are also convinced that 'building democracies is about building democratic institution', an institutionalised party system is a must for democratic consolidation, and that parties competing in the election must be properly organised (Mainwaring and Scully, 1999: 1, 4-5, 21, 23, 27).

Gunther et al started their book by discussing whether literature on parties is enough for students of this field. They quoted a statement that since 1945 there are 11,500 books on parties and party systems in Western Europe alone, in 1988 Gunther, 2002: 2). They did admit that there was a waning of scholarly interest in political parties during the early 1990s, but claim that there was an 'outburst' of comparative studies on parties, and the appearance of the Party Politics journal, which more than reawakened the somewhat slugging attention in the field (Gunther, 2002: 3). They believe that the study of political parties, although 
accused of being old-fashioned and out-of-date, is instead a challenging branch that has attracted a lot of renewed interest.

The list of literature presented by Gunther et al shows that this study is very much Western-based. All the names they mentioned in the list were Europeans, demonstrating the less attention received by other parts of the world when it comes to study on political parties. Indeed, Western countries are seen as the 'more established' and have more experience with democracy - thus making them the first also to encounter most contemporary 'party issues', while the countries that are still new to democracy are also still learning about it. The waves of democratisation (borrowing Huntington's term), although also hitting parts of Asia, have attracted less attention compared to, for example, Eastern and Southern Europe (Stepan and Linz, 1996).

The works based on the effects of democratisation in Asia have been countrybased and do not explore much of the political parties (Uhlin, 1997). The scholarly works on parties in Asia tend to focus on either individual countries or parties, and there is very little effort, if any, to distinctly theorise or categorise the parties in Asia as scholars did for Europe. Gunther et al have acknowledged that parties in East Asia have played important role in democratising their countries (Gunther et al., 2002: 58), but so far there are only limited number of books on parties in, for example, Korea and Japan (see for example the works of Mikiso Hane and Junichiro Wada). Furthermore, there is limited works on parts outside Western countries in terms of efforts to generalise a group of political parties in the region, compared to other regions (see for example Linz and Stepan's work in Stepan and Linz, 1996).

\section{ORGANIZATION OF PARTIES}

Benjamin Constant described a party as 'a group of men professing the same political doctrine' in 1816 (Duverger, 1954: xiv). Initially these men will be drawn to a particular party by its programme, but later the party organization would also play an important part in uniting these supporters (Duverger, 1954: xiv-xv). Duverger, whose book was published in 1954, presented the basic elements in a party as: the caucus (can also be called a committee or a clique) - the small, exclusive, powerful group of notabilities who are only active around the election period; the branch that continually extends its membership and remains active outside election period; the cell - which has an occupational basis but smaller than the branch; and the militia or the army-trained support group (Duverger, 1954: 17-40).

A more modern and complicated organisation of political parties is described by Kenneth Janda and Tyler Colman, who believes that an ideal party 'engage in activities that have functions for society' - activities are what the parties do, while functions are what scholars see as the social consequences of those activities (Janda and Colman in Hofferbert, 1998: 195). They measured the organisation of party by its electoral success, breadth of activities, and its cohesion (Janda and 
Colman in Hofferbert, 1998: 194). Electoral success is measured from votes won, seats won, and governments formed, while the 'breadth of activities' is measured from the aspects of propagandizing ideas and programs, and providing for members' welfare (Janda and Colman in Hofferbert, 1998: 194-195). The propaganda aspect involves: passing resolutions and platforms, publishing position papers, operating party schools, and operating mass communication media (Janda and Colman in Hofferbert, 1998: 195). The welfare aspect contains: providing food, clothing and shelter to members from party resources; running employment services; interceding with government on members' behalf; providing basic education in addition to political education; and providing recreational facilities or services (Janda and Colman in Hofferbert, 1998: 195).

Janda and Colman also give detailed indicators of how to measure a party organisation - which is by looking at four components: complexity, centralization, involvement, and coherence (Janda and Colman in Hofferbert, 1998: 196). They break down the components further. Complexity is measured by looking at: structural articulation, intensiveness of organisation, extensiveness of organisation, frequency of local meetings, maintaining records, and pervasiveness of organization (Janda and Colman in Hofferbert, 1998: 196). Centralisation is measured by: nationalisation of structure, selecting national leader, selecting parliamentary candidates, allocating funds, formulating policy, controlling communications, administering discipline, and leadership concentration (Janda and Colman in Hofferbert, 1998: 196-197). Involvement involves: membership requirements, membership participation, material incentives, purposive incentives, and doctrinism (Janda and Colman in Hofferbert, 1998: 197). Coherence or factionalism involves: ideology, issues, leadership, and strategies or tactics (Janda and Colman in Hofferbert, 1998: 197).

One of the aspects of party organisation that has attracted a significant portion of scholars' attention is partisanship. The debate on partisanship has again concentrated on Western parties. Duverger differentiates the degree of participation as: electors (easily measurable by the number of votes), supporters ('something more than an elector and something less than a member'), militants (active members, the executives of party) (Duverger, 1954: 91-116). A large portion of study on this area has focused on the comparison between American and Western parties, as described by Schmitt and Holmberg, and on how there are differences between the origins of partisanship in both regions, which required that there should be different systems to measure partisanship in the different areas (Schmitt and Holmberg in Klingemann and Fuchs, 1995:98). The concerns over the decline of partisanship (as briefly mentioned in the first section) has been intensified by the argument that such trend could result in political apathy, greater sentiment against the prevailing political order, political cynicism and distrust - but at the same time it provides opportunities for new parties (Schmitt and Holmberg in Klingemann and Fuchs, 1995: 100). 
The degree of partisanship can be roughly measured by looking at the size, age, the ideological position, and the political family of the party (Schmitt and Holmberg in Klingemann and Fuchs, 1995: 118). Scholars initially found that identification with larger parties grew stronger as people age whereas bonds with smaller parties get weaker and tend to diminish as people age (Schmitt and Holmberg in Klingemann and Fuchs, 1995: 118). This is because it is easier to switch from a small party to another than from big party to another (Schmitt and Holmberg in Klingemann and Fuchs, 1995: 118). However, Schmitt and Holmberg found that there is only weak support for the age argument, and that young parties do not necessarily have less time or opportunity to build support (Schmitt and Holmberg in Klingemann and Fuchs, 1995: 119). In terms of the age of parties, because it takes time to build a stable ties with a party, older parties tend to have more stable group of identifiers (Schmitt and Holmberg in Klingemann and Fuchs, 1995: 118). Ideological position also determines the degree of attachment, as the more extreme the ideology of a party the more likely they attract 'true believers' (Schmitt and Holmberg in Klingemann and Fuchs, 1995: 118). In terms of political family, there are indications suggesting that parties with traditional working-class or middle-class electorate (socialist or Christian-democratic parties, for example) receive greater support as people identify emotionally with them (Schmitt and Holmberg in Klingemann and Fuchs, 1995: 118).

Lawson identifies different party linkages as: participatory, electoral, clientilistic, and directive (Widfeldt in Klingemann and Fuchs, 1995: 135). Directive linkage is relevant only to dictatorship or authoritarian regime, and electoral and clientilistic linkage can be summarised as representative linkages (Widfeldt in Klingemann and Fuchs, 1995: 135). When a party form linkages by getting ordinary people interested or actively involved in politics, the linkages is called participatory linkage (Widfeldt in Klingemann and Fuchs, 1995: 135). When the linkage is performed by representing citizens, it is called representative linkage (Widfeldt in Klingemann and Fuchs, 1995: 135).

One of the most important indicators of the linkage status of a party is its membership strength - no parties could claim to have a healthy linkage status if it does not attract members and parties with only few members are limited in functioning as a participatory linkage (Widfeldt in Klingemann and Fuchs, 1995: 136). To define someone as a party member is not easy as parties have different definitions, but generally a member has a certain degree of active interest and is formally enrolled as a member (Widfeldt in Klingemann and Fuchs, 1995: 136). To continue on the notion that there is a decline of parties (notably in Europe), Richard Katz and Peter Mair note that the elements of the parties outside of public office is disappearing - meaning the 'faces' of parties in central office and party on the ground are withering away (Katz and Mair in Gunther et al., 2002: 126). Yet another supporting fact for the notion that parties are declining is that among thirteen long-established democracies in Western Europe party membership has 
fallen from an average of almost 10 percent in 1980 to less than 6 percent at the end of 1990s (Katz and Mair in Gunther et al., 2002: 126).

However, at the same time, there seems to be indications that party memberships, although declining in percentage, are in fact empowered by parties opening-up decision making procedures, including candidate and leadership selection process to general party members (Katz and Mair in Gunther et al., 2002: 126-127). The trend of internal democratisation has been one of the subjects of interest for other scholars such as Rachel Gibson and Robert Harmel (Gibson and Harmel in Hofferbert, 1998: 211-228). Other research has also indicated that there is a 'widening participation' in the process of candidate and leadership selections in parties, and general members have greater say in the processes (Hasan in Le Duc, Niemi and Norris, 2002: 117, 123).

If it is true that the organisation of party is crucial for its members to maintain support for it, then it is essential for parties to develop an organisational system that is preferred by members and supporters. After all, if party loyalty is declining in Europe, the parties there need to be 'reminded' that their members are the determinant in their survival. As Hofferbert claims, 'much of democratic control rests not only on voters' ability to make meaningful electoral choices predictive of policy performance, but also on the ability of voters to inflict retrospective electoral punishment for party failure' (Hofferbert, 1998: 7). That applies for both party in the office and party on the ground, meaning that not only the party leaders have to be successful in representing the members' interest, party on the ground has to be well-organised as well to appeal to voters.

\section{PARTY TYPOLOGIES}

Wolinetz argue that classifying parties is 'surprisingly' difficult - and "students of political parties have typically worked around as with classificatory schemes, employing them where they are useful and ignoring or omitting them where they are not" (Wolinetz in Gunther et al, 2002: 138). He argues that party classification has been so limited because comparative study of political parties is a mainly West European venture, and efforts to include parties from other parts of the world have not been comprehensive (Wolinetz in Gunther et al, 2002: 138). Furthermore, there is more attention for party systems than parties, their organisation, or the ways in which they should be classified (Wolinetz in Gunther et al, 2002: 138).

Richard Gunther and Larry Diamond stated two reasons of why the existing typologies are still not comprehensive enough. Firstly, along the same line with Wolinetz, Gunther and Diamond believe that the problem is caused by the fact that the typologies were based on studies of West European parties over the past century and a half (Gunther and Diamond, 2003: 168). The parties in other parts of the world were faced by different 'social and environmental situations' and thus have different features - even parties in the US do not fit in the typologies (Gunther and Diamond, 2003: 168). The second problem with the typologies is that they are based on criteria that are too wide, and there has been no effort "to 
make them more consistent and compatible with one another" (Gunther and Diamond, 2003: 169).

Duverger (1954) presented one of the first typologies, which differentiated parties as mass parties and cadre parties. In terms of members, mass parties concentrate on the number of them; while for cadre parties what matters is the quality of the members (Duverger, 1954: 63-64). In mass parties there is a formal machinery of enrolment for members, which entails tasks and subscriptions to pay; while in cadre parties admission is accompanied by no official formalities, the periodic subscription is replaced by occasional donations (Duverger, 1954: 71). For cadre parties, "the adherent's activity within the party can determine the degree of participation" (Duverger, 1954: 71). Mass parties depend on the number of members to accumulate funds for their operations, while cadre parties rely on the quality of their candidates to attract financiers (Duverger, 1954: 64).

Neumann (1956) presented a differentiation between parties of individual representation and parties of democratic (mass) integration. Neumann thinks that while initially parties were mainly the vehicle of individual's interests; modern individuals who are part of the 'rising, self-conscious middle class that fought for liberation from the shackles of a feudal society' were soon striving to re-integrate into the new society, and the parties are the means of that process (Neumann, 1956: 403-404). Membership activity for parties of individual representation is limited to voting and nothing else between election periods, and candidates selected for public office has no accountability and responsibilities to the party members (Neumann, 1956: 403-404). On the other hand, parties of integration have an increasing influence over all aspects of individual's life (Neumann, 1956: 403-404).

Panebianco (1988) pointed to Kirchheimer's catch-all party classification, which claims that Duverger's mass parties have evolved into an organisation that has opened up to a much wider range of social groups as members (Panebianco, 1988: 263). Panebianco believes that Kirchheimer's analysis actually brought to surface the increasing professionalism of party organizations (Panebianco, 1988: 264). He then builds upon this fact to construct his typology of mass bureaucratic parties (membership party, strong vertical organizational ties, financing through membership), and electoral-professional parties (central role of the professional tasks, electoral party, weak vertical ties, financing through interest groups and public funds) (Panebianco, 1988: 264).

Koole updated and modernised the definition of cadre parties with his modern cadre parties. Koole $(1992,1994)$ drew his definition of characteristics of the modern cadre parties from the Dutch political parties, who enlist only a small percentage of their supporters as members. The characteristics of the parties are, among others: a low member/voter ratio, maintain the structure of mass party, and the reliance for financial resources on a combination of both public subsidies and the fees and donations of members (Wolinetz in Gunther et al, 2002: 141142). 
However, what has been the focus of a lot of attention is Katz and Mair's typology of cartel party. Wolinetz argues that Katz and Mair's typology is an addition of Neumann's typology (Wolinetz in Gunther et al, 2002: 148). Cartel parties' characteristics are defined by the relationship between the party and the state - after parties find themselves 'vulnerable to the vagaries of the electorates who have detached themselves from previous political moorings' (Wolinetz in Gunther et al, 2002: 148). As the members' loyalty decreases, parties open themselves to state subsidies for financial support. This in turn influenced party leaders to limit competition and concentrate on the new resources (Gunther and Diamond, 2003: 169). The subsidies of parties and special access to stateregulated channels of communications are major help for the parties to maintain their position, instead of the sheer size and membership commitments (Klima in Hofferbert, 1998: 84). Amidst the significant extent of discussion on cartel party, Michal Klima however argues that no pure cartel party exists (Klima in Hofferbert, 1998: 84).

Steven Wolinetz himself presented his typology that is based on the orientation of parties, whether they are policy-, vote-, or office-seeking. He emphasised that the orientation or goal is not exclusive of one another, and that it is more about the priority of the particular party (Wolinetz in Gunther et al, 2002: 150). The characteristics of the different types are shown in the table 1.

David Olson presented a typology specific for new democracies in Europe. He used Duverger's typology of cadre parties, but argues that for the leaders of the cadre parties in new democracies democracy is a 'preferred condition'; and that cadre appeals more than the mass party as they need to concentrate on votes rather than building a mass organization (Olson in Hofferbert, 1998: 23). As a strategy for elections, parties in new democracies tend to differentiate themselves between historical and post-transition parties (Olson in Hofferbert, 1998: 24). The historic parties tend to have an existing group of supporters and a structured relationship between voter and leader, while the new parties tend to appeal to floating electorate and have no pre-existing organization (Olson in Hofferbert, 1998: 24). 
Table 1. Wolinetz' Typology of Parties

\begin{tabular}{|c|c|c|c|}
\hline \multirow[t]{2}{*}{ Possible indicators } & \multicolumn{3}{|c|}{ Parties } \\
\hline & Policy-seeking & Vote-seeking & Office-seeking \\
\hline \multicolumn{4}{|l|}{$\begin{array}{l}\text { Internal policy } \\
\text { debate }\end{array}$} \\
\hline $\begin{array}{l}\% \text { of time spent at } \\
\text { party meetings }\end{array}$ & High & Low & Low \\
\hline $\begin{array}{l}\text { Character of } \\
\text { debate }\end{array}$ & $\begin{array}{l}\text { Intense, } \\
\text { protracted, issue- } \\
\text { focused }\end{array}$ & $\begin{array}{l}\text { Pro forma, diffuse, } \\
\text { unfocused }\end{array}$ & $\begin{array}{l}\text { Pro forma, diffuse, } \\
\text { unfocused }\end{array}$ \\
\hline $\begin{array}{l}\text { extent and level of } \\
\text { involvement }\end{array}$ & $\begin{array}{l}\text { Extensive, most } \\
\text { levels of party } \\
\text { involved }\end{array}$ & $\begin{array}{l}\text { Confined to } \\
\text { leadership or policy } \\
\text { committee, } \\
\text { compartmentalized }\end{array}$ & $\begin{array}{l}\text { Confined to } \\
\text { leadership or policy } \\
\text { committee, } \\
\text { compartmentalized }\end{array}$ \\
\hline $\begin{array}{l}\text { Consistency of policy } \\
\text { positions assumed }\end{array}$ & High & $\begin{array}{l}\text { Medium to low, prone } \\
\text { to change depending } \\
\text { on leader's directions, } \\
\text { electoral opportunity } \\
\text { structure }\end{array}$ & Medium to low \\
\hline \multicolumn{4}{|l|}{ Election campaigns } \\
\hline $\begin{array}{l}\text { prominence of } \\
\text { policy }\end{array}$ & High & Varies & Low \\
\hline $\begin{array}{l}\text { determination of } \\
\text { strategy }\end{array}$ & $\begin{array}{l}\text { Follows from } \\
\text { policies }\end{array}$ & $\begin{array}{l}\text { Policies developed to } \\
\text { fit strategy, maximise } \\
\text { votes }\end{array}$ & $\begin{array}{l}\text { Varies, preference for } \\
\text { low-risk strategies }\end{array}$ \\
\hline $\begin{array}{l}\text { use of new } \\
\text { electoral } \\
\text { techniques }\end{array}$ & Low to medium & High & Low to medium \\
\hline $\begin{array}{l}\text { Infrastructure to } \\
\text { support policies (e.g } \\
\text { research bureaux, } \\
\text { think-tanks, } \\
\text { affiliated } \\
\text { organisations }\end{array}$ & Present & $\begin{array}{l}\text { Either minimal or at } \\
\text { disposal of leaders, } \\
\text { office-holders }\end{array}$ & $\begin{array}{l}\text { Either minimal or at } \\
\text { disposal of leaders, } \\
\text { office-holders }\end{array}$ \\
\hline \multicolumn{4}{|c|}{$\begin{array}{l}\text { Source: Steven B. Wolinetz, "Beyond the Catch-All Party: Approaches to the Study of Parties } \\
\text { and Party Organization in Contemporary Democracies", in Richard Gunter et al (eds.), } \\
\text { Political Parties: Old Concepts and New Challenges, (Oxford: Oxford University Press, 2002), } \\
\text { p. } 155 .\end{array}$} \\
\hline $\begin{array}{l}\text { Gunther and } \\
\text { presenting their typ } \\
\text { programmatic comr } \\
\text { pluralistic, or proto }\end{array}$ & $\begin{array}{l}\text { Diamond assesse } \\
\text { ology, which is } \\
\text { hitments, and st } \\
\text {-hegemonic in it }\end{array}$ & $\begin{array}{l}\text { and criticised the } \\
\text { ad on three criteria } \\
\text { gy and behavioura } \\
\text { jectives) (Gunther }\end{array}$ & $\begin{array}{l}\text { xisting typologies - } \\
\text { formal organization, } \\
\text { רorms (tolerant and } \\
\text { nd Diamond, 2003: }\end{array}$ \\
\hline
\end{tabular}


171). Their thirteen party types are grouped into: elite-based parties, mass-based parties, ethnicity-based parties, electoralist parties, and movement parties (Gunther and Diamond, 2003: 172). The elite-based parties refer to 'those whose principal organizational structures are minimal and based upon established elites and related interpersonal networks within a specific geographic area", and the types of parties that belong to this group are the traditional local notable party (the first type of party to emerge, simple in organisation, and based on traditional personal relationships), and clientelistic party (parties that emerged in industrialised and urbanised societies; is a confederation of notables with geographically, functionally, or personalistically based support; and has a weak organisation) (Gunther and Diamond, 2003: 175-176). The mass-based parties group emerged as a manifestation of the political mobilisation of the working class in many European polities", consisting of: denominational (have large base of duepaying members, hierarchically structured, based programmes on religious beliefes), fundamentalist (seek to reorganise party around strict religious doctrines), pluralist-nationalist (have mass membership, extensive organisation, supporters belonging to a distinct national group), ultranationalist (prioritise the nation above individuals, admires the use of force, selective recruitment), Leninist (aims to overthrow existing system and have a closed structure based on semisecret cell), and class-mass (the centre of power in executive committee of secretariat, have an open and tolerant stand) parties (Gunther and Diamond, 2003: 178-183). Ethnicity-based group consist of: the purely ethnic party (seeking to gather votes based on a particular ethnic group), and congress party (an alliance or coalition of ethnic parties, that appeal to national unity and integration) (Gunther and Diamond, 2003: 183-184). The electoralist group consists of: catchall party (shallow organisation, vague ideology, and overwhelmingly electoral orientation), programmatic party (modern, pluralist, thinly organised, main function is the conduct of election campaigns, has coherent ideological agenda), and personalistic party (only to provide a vehicle for personalities to win elections) (Gunther and Diamond, 2003: 185-188). The group of movement parties consists of: left-libertarian (reject the high status of economic issues, open membership, strong commitment to direct participation), post-industrial extreme right (emphasise self-affirmation, informality, and libertarianism) parties Gunther and Diamond, 2003: 188-189).

\section{TOWARDS A MORE INCLUSIVE DISCUSSION}

The study of political parties is definitely a Western-dominated area. Since the early development of theorisation on political parties, Western scholars have focused their attention on West European parties. Countries in Western Europe have more experience with democracies and parties and thus became the examples for less-developed countries. For scholars who are interested in studying parties from other parts of the world - although there are inevitable differences in 
circumstances where the parties have developed, there are aspects of Western studies of political parties that can be utilised, as I mention below.

Political parties are inevitable in democracies. The full-functioning of a free electoral system is crucial for the functioning of democracy. Although partisanship and membership has arguably declined as a result of modernisation, there is also a growing internal democratisation within the parties, whereby members are given more power to influence decisions in the parties. This trend is likely to continue as citizens increasingly become floating voters and they may make the decision of which party to support based on which party gives them the most influence.

It would also be useful to draw from the experience of Western countries in terms of party organisation. Because they are more advanced, the Western parties are arguably more sophisticated, compared to their counterparts from other regions in the world. The range of activities and indicators of party organisation presented by Janda and Colman can be used for any party to determine how developed it is. The degree of partisanship and indicators to measure it, presented by Schmitt and Holmberg, are also useful for every party or party enthusiasts to utilise. To categorise parties has been difficult. There are various aspects to consider when developing a typology, thus most of the typologies are not comprehensive and cannot be used for parties from other regions. The elaborate typology presented by Gunther and Diamond looks promising for including parties from other regions.

Although discussion on political parties is still Western-dominated, more attention needs to be shifted to include other regions. The recent development of political parties in Indonesia, for example, deserves more attention from political scientists. Western scholars are not in denial about the fact that they have been too Western-oriented, and the typology by Gunther and Diamond is promising in terms of the effort to develop a more comprehensive approach of political parties. It remains to be seen, however, how much more attention that will be given to parts outside the Western countries to study political parties.

\section{ACKNOWLEDGEMENT}

The Author would like to acknowledge and thank you A/Prof. David Reeve, The University of New South Wales (UNSW) for his invaluable advice; which made this article possible.

\section{REFERENCES}

Duverger, Maurice. 1954 . Political Parties: Their Organization and Activity in the Modern State. London: Methuen and Co.

Gunther, R., and L. Diamond. 2003. Species of Political Parties: A New Typology. Party Politics. Vol. 9, No. 2. 
Gunther, R., J. R. Montero., and J. J. Linz. 2002. Political Parties: Old Concepts and New Challenges. Oxford: Oxford University Press.

Hadenius, A. 1997. Democracy's Victory and Crisis: Nobel Symposium No. 93. New York: Cambridge University Press.

Hofferbert, R. (ed.) 1998. Parties and Democracy: Party Structure and Party Performance in Old and New Democracies. Oxford: Blackwell.

Huntington, S. 1993. The Third Wave: Democratization in the Late Twentieth Century. Norman: University of Oklahoma Press.

Klingemann, H., and D. Fuchs (1995). Citizens and the State. Oxford: Oxford University Press.

Le Duc, L., R. G. Niemi, and P. Norris. 2002. Comparing Democracies 2: New Challenges in the Study of Elections and Voting. London: Sage.

Linz, J. J., and A. Stepan. 1996. Problems of Democratic Transition and Consolidation: Southern Europe, South America, and Post-Communist Europe. Baltimore; London: The John Hopkins University Press.

Mainwaring, S., and T. Scully 1995. Building Democratic Institutions: Party Systems in Latin America. Stanford: Stanford University Press.

Michels, R. 1959. Political Parties: A Sociological Study of the Oligarchical Tendencies of Modern Democracy. New York: Dover Publications.

Neumann, S. 1956. Modern Political Parties: Approaches to Comparative Politics. Chicago: University of Chicago Press.

Norris, P. 2002. Democratic Phoenix: Reinventing Political Activism. Cambridge: Cambridge University Press.

Panebianco, A. 1988. Political parties: Organization and Power. Cambridge: Cambridge University Press.

Pridham, G. 1995. Transitions to Democracy: Comparative Perspectives from Southern Europe, Latin America, and Eastern Europe. Aldershot: Dartmouth.

Uhlin, A. 1997. Indonesia and the Third Wave of Democratization: The Indonesian Pro-Democracy Movement in a Changing World. Surrey: Richmond. 